\title{
Assessing the Ecological Impacts of Bioenergy Projects
}

\author{
Les G. Firbank
}

Published online: 26 January 2008

(C) The Author(s) 2007

\begin{abstract}
One of the major objectives of the current expansion in bioenergy cropping is to reduce global greenhouse gas emissions for environmental benefit. The cultivation of bioenergy and biofuel crops also affects biodiversity more directly, both positively and negatively. Ecological impact assessment methods for bioenergy projects (including changes to policy and land use) should address not simply changes to species abundance at field level, but include larger scale issues, including changes to landscape diversity, potential impacts to primary and secondary habitats and potential impacts on climate change. Such assessments require a correspondingly broad range of scientific methods, including modelling of climate and land use as well as the observation of biodiversity and landscape indicators. It is also possible to adopt evidence-based guidelines for good practice for situations where comprehensive assessments are not available. These might include favouring projects and policies that avoid gene flow to wild relatives of crops in centres of diversity, that do not result in invasion by the crop into other habitats, that enhance fieldscale biodiversity, that increase landscape diversity, that do not threaten valued habitats within the local landscape, that promote the sustainable management of biodiverse habitats, that do not increase the risk of loss of primary habitats and that result in a proportionately large reduction in greenhouse gas emissions.
\end{abstract}

Keywords Biofuel · Biodiversity - Environmental risk assessment $\cdot$ Land use change $\cdot$ Land use conflict

\section{G. Firbank $(\bowtie)$}

Institute of Grassland and Environmental Research,

North Wyke,

Okehampton, England EX20 2SB, UK

e-mail: Les.firbank@bbsrc.ac.uk

\section{Introduction}

One of the factors driving the current interest in bioenergy cropping is the potential environmental benefit through the reduction in greenhouse gas emissions [57]. However, any major changes in land use have the potential to impact other aspects of the environment. It is clear that intensive agriculture and forestry have undermined the delivery of ecosystem services in many parts of the world as a result of impacts on biodiversity [43]. It is also clear that biodiversity is also under threat from global environmental change [63]. Bioenergy cropping therefore has the potential to benefit biodiversity by mitigating against climate change. However, it is important to consider the potential impacts on biodiversity as a result of changes in land use and management [38]. The purpose of this paper is to consider the issues that need to be addressed when assessing the impacts of bioenergy crops on biodiversity, and the methodologies that are available. The paper also considers potential guidelines for good practice for bioenergy cropping in the absence of a complete assessment.

For an ecological impact assessment, the processes that relate the proposed changes to effects on biodiversity need to be each understood as a function of some form of hazard or potential benefit and the probability of its occurrence. The hazard or benefit arises from a change in a pressure (using terminology from the OECD driver-pressure-stateimpact-response model for managing environmental change [44]) that directly impacts one or more components of the environment. Such impacts are observed through changes to measurable indicators.

An important precedent for assessing potential impacts of new cropping patterns on biodiversity is the process of environmental risk assessment of genetically modified (GM) crops. Early risk assessments considered the potential 
for environmental harm arising from the crop plants themselves. The introduction of the new varieties constituted the pressure that could cause ecological impacts by being toxic to non-target organisms and by affecting the gene pools of wild relatives. While these potential hazards could be explored in the laboratory, the probability of the hazard materializing required field work of considerable scale [56, 71]. These assessments did not address the indirect effects arising from how the crop plants are managed, notably the pressures of new combinations of pesticides and herbicides associated with the crops and their impacts on arable plants, invertebrates and birds [39]. New experiments were devised to estimate these effects through comparison of biodiversity indicators for GM and non-GM cropping systems [18]. While it proved possible to establish the extent of differences between these two systems at field level [5, 17, 29, 31], these differences were not constant; they could be mitigated by changes to crop management [11] and were sensitive to the scale of cropping at the landscape level [15]. Moreover, because the differences observed between GM and non-GM cropping were smaller than those found between crop species [5, 17, 29, 31], it was not clear that the effects of GM cropping were any greater than those involved with other changes in agricultural land management [15].

There are important aspects of the design of risk assessments of GM crops that are inappropriate for those of most introductions of bioenergy crops. The risk assessments assumed that GM crops might replace conventional varieties of the same species, rather than change cropping patterns substantially. This assumption might have been reasonable for the case of GM crops, and may be valid for varieties of existing arable crops being planted for biofuel. But it does not hold for plantings of bioenergy crops such as willow (Salix spp.), poplar (Populus spp.) and Miscanthus (Miscanthus spp.), especially if they replace very different land covers such as grassland or annual row crops. Ecological risk assessments of GM crops are triggered by how the crop has been bred, rather than how it will be used, while for bioenergy crops the effects of cultivation practices, choice of areas and crop species are likely to have bigger environmental impacts than the methods of plant breeding [15]. Risk assessments for GM crops in Europe adopt the position that effects on biodiversity should be no less than the comparable conventional crop [14], but this position is more complex to evaluate for bioenergy crops as they are expected to have a broader environmental benefit as well as local impacts.

A broader understanding is required that addresses potential impacts on biodiversity of bioenergy (and, by implication, biorefinery) projects that impact on land use and land management. These projects might be new varieties, new policies or new commercial opportunities.
They could be at a very local scale, such as a proposal to plan bioenergy crops near a nature reserve, or to manage a local forest for harvesting biomass. They could be technological, for example the development of genetically modified varieties of bioenergy crop plants, or they could be policy related, whether aimed at national energy security or the global control of greenhouse gas emissions. A framework is needed that addresses potential positive and negative impacts on different taxa at differing spatial and temporal scales, recognising that there might be acceptable trade-offs between localised risks and benefits to biodiversity compared to larger scale, longer-term impacts. It is helpful to separate impacts at the global, regional, landscape and crop scale, not because they are independent [19], but at least this distinction helps isolate particular processes and how they might be assessed.

This paper discusses the ecological impacts that should be considered when constructing risk assessments for bioenergy projects that involve changes in land use and management, noting the key questions to be addressed and the methodologies available.

\section{Field Scale}

\section{Pressures}

The lowest level change at field level in a bioenergy project is that the use of the crop is changed, but not the crop itself, e.g. using grass for bioenergy production instead of grazing [66]. The next level is that of swapping varieties of the same species, as may happen with arable biofuel crops and tree plantations. It is also likely that the new varieties will involve different levels of fertiliser and pesticide inputs, analogous to changes in pesticide regimes associated with GM crops.

It is also likely that the crop species itself is changed. This can be more than swapping one arable species to another, and may involve substantial changes to the growth form, phenology and disturbance regime, as happens by the replacement of grassland, conservation reserve or annual row crops with biomass crops.

\section{Impacts}

The impacts on biodiversity at the field level include the potential for gene transfer to wild relatives. This potential is considered an important risk to biodiversity should the new crop be genetically modified [37, 49], and especially if the crops are located in an area of genetic diversity [15]. There is the potential for direct effects on those taxa that reply on the crop plant, directly or indirectly.

A simple switch between varieties of the same species can influence the species in and around the crop [12], 
especially if the switch is also associated with changes to crop management [15]. The effects tend to be of a similar order to other changes in agricultural practice [15].

Changes to the gross growth form and phenology of the crop are likely to result in much greater effects on more species. Their cultivation is likely to eliminate niches for some species, but open up other niches for others; not simply modifying the existing ecology, but introducing a new suite of species. This would happen, for example, when grassland is transformed into forestry. The issue then is not simply the loss of the grassland habitat and the biodiversity associated with it, but also the gain of a new forest habitat, and its potential quality compared with other secondary woodlands.

The key questions to be asked as part of an assessment are, therefore,

- What is the potential for gene flow to wild relatives?

- If the new crop does not involve a major change in growth form from existing land use, what is the potential for direct and indirect impacts on the species associated with it?

- If the new crop involves a major change in growth form, what is the potential biodiversity compared to (a) the existing land use and (b) existing habitats of similar structure to the new crop?

\section{Methodologies}

The methods used to answer these questions all involve the choice of indicators, selected by considering the process by which the pressure may have an effect. While methods of assessing gene flow are well established, the question of how much gene flow is acceptable in ecological terms is more contentious [3, 49]. Likewise, methods of establishing both hazard of toxicity effects on non-target organisms and the likelihood of such hazards being realised are well understood [56].

The UK Farm Scale Evaluations of GM crops established a robust method for assessing risks to biodiversity resulting from changing one cropping system to another [18]. It involved establishing a set of indicator species that were monitored in a randomised block experiment in which the two treatments corresponded to GM and non GM cropping systems of the same crop species-i.e. GM maize was compared with conventional maize. The experiment was designed to test the null hypothesis of no difference between indicator levels between treatments [46]. The observed effects were extrapolated to longer time scales [30] and to other taxa [23].

This null hypothesis is appropriate for designing experiments when the differences between the two systems are small, but is not appropriate when the change involves the transformation of habitats. This is because most biodiversity indicators will be associated with one or the other habitat (e.g. grassland vs forest). Moreover, the species composition during the early years of such a transformation may not reflect that to be found once the habitats are mature. A more appropriate approach would be to consider the ecological quality of the present and proposed land uses compared with similar habitats. Thus the loss of a speciespoor, intensive grassland would be more acceptable than that of a species-rich meadow, especially if the new habitat is to be managed in ways that enhance its biodiversity potential. The quality of existing habitats can be tested on the ground [58] or using existing conservation databases and designations. While the potential for biodiversity of new habitats is best determined on the basis of experimental evidence, models are appearing that forecast the potential species occupancy on the basis of the niches that will become available $[9,48]$.

\section{Landscape Scale}

\section{Pressure}

Transitions between annual crops, grazing land, biomass grasses, coppice and forest involve the creation and destruction of habitats. The implications of such changes are not simply restricted to the land parcels themselves, but to the biodiversity of the whole landscape. This is due to the importance on the spatial structure and turnover of habitats within a landscape to many species [19].

The first pressure is that of changing the use of different parcels of land. The issues involved from changing from one crop type to another are noted above, but it is also possible that land is brought into cropping from other uses, including semi-natural or even primary habitats. Such changes will affect the diversity of land use within a landscape, making it more uniform in the case of large scale plantings or more diverse in the case of small parcels of biomass crops. A second pressure is to change the structure of the landscape itself, for example by dividing or aggregating existing land parcels into smaller or larger units, and by creating or destroying non-cropped features in the landscape such as hedgerows or buffer areas. Bioenergy cropping may impose a third pressure, by changing the rate of turnover of habitats, for example as new rotations are introduced to coppice or arable cropping.

\section{Impacts}

The biodiversity of a landscape is closely related to the quality of individual habitats, the diversity of habitats, their turnover and the spatial relationships among them. In agricultural 
landscapes, habitat quality is often a function of the history of land management, with the most biodiverse habitats being those that have had continuity of less intensive practices [35]. At the landscape scale, it is generally true that the greater the diversity of habitats, the greater the diversity of species [4, 19], though habitats managed traditionally at large scales, such as steppe, have their own assemblages of high conservation value. This diversity is increased when the spatial structure of the landscape facilitates dispersal of organisms between habitat patches [28], which is why the biodiversity of farming systems is dependent upon the landscape character as well as on the management of the individual parcels of land [22, 34, 70].

A major negative potential impact on biodiversity is the loss of a high-quality habitat, either by its replacement by a bioenergy crop or by large changes in its management (e.g. increased extraction of woodfuel from woodland). A second negative impact would arise should the introduced crop species prove invasive, especially likely in the cases of grasses including giant reed (Arundo donax) and, potentially, Miscanthus [50]. The risk of invasiveness needs to be addressed when considering the location of the crops in the landscape. For example, there are potential benefits in planting bioenergy crops adjacent to high quality habitats, so that they act as buffers for control of water quality and/or microclimate. However, this would be inappropriate for the giant reed, as it is known to invade riparian habitats [50].

The greatest potential benefit at the landscape scale is from the creation of new habitats by planting bioenergy crops, especially woodland and short rotation coppice. While the new crop will gain a new suite of species, there are time lags as the crops themselves grow and mature, and as species immigrate into the new habitats or become locally extinct. These time lags vary among species, and depend on their presence in the vicinity [59], which in turns depends upon the landscape structure and its past management [59]. They may be surprisingly long. For example the distribution of a carabid beetle in an agricultural landscape in 1993 was actually better correlated with the distribution of its hedgerow habitat in 1952 than the contemporary pattern [47], while the plant species diversity in a Swedish agricultural landscape is best explained by land use patterns 200 years ago [27].

Another potential impact is through the removal or addition of linear habitat features and small areas of seminatural habitats, such as lines of trees, hedgerows, wateredge and ponds, with consequent losses of habitat and potential corridors for species dispersion [8, 13]. Again, there is the potential to use bioenergy crops as buffer zones to reduce soil losses or diffuse pollution into watercourses [1], whilst creating habitat for some species.

While habitat turnover can reduce the abundance of many species that have poor dispersal abilities, it is required for the persistence of some early-succession plant and animal assemblages. This is particularly true for the forest floor flora that became associated with woodland coppice in north-west Europe. Willow and poplar coppice for bioenergy can be beneficial for these species, but only if the new rotations are in phase with the dispersal, life cycle and dormancy patterns of the species involved [10].

The key questions to be asked as part of an assessment are, therefore,

- Does the proposal threaten, or buffer, existing high quality habitats in the landscape?

- Does the proposal affect landscape diversity, structure and turnover?

- Is the crop likely to prove invasive in its new environment?

- Is there potential for species losses or gains through landscape modification?

\section{Methodology}

Any change at the landscape will affect some species positively, and others negatively. It is therefore important to identify the priorities for biodiversity conservation, and how their needs may be met should the landscape change. These priorities are likely to focus on either individual species or habitats, or a more generalised desire to increase diversity. The issue of individual species or habitats arises when their presence in the landscape is already known, their conservation importance already established, and any management criteria understood. Potential proposals should be challenged against these criteria, and methods sought that improve the viability of the species of habitats by, for example, acting as buffer zones for microclimate or water quality control, or by creating potential networks for species dispersal.

The ideal methodologies for assessing potential impacts of new developments for a broader range of taxa involve the use of baseline data on both landscape and biodiversity, as well as the means for assessing the potential impacts of changing the landscape. There are many approaches to landscape and biodiversity inventory and monitoring [16, $25,36,51]$ : in general, landscapes can be monitored using remote sensing, but species assessments need to be made on the ground. Models are becoming available to help forecast impacts of changes on higher plants, invertebrates, birds and mammals. It is possible to evaluate the viability of landscapes for multiple taxa according to the area and configuration of habitats they require [6, 62]; it is also possible to model the biodiversity of a potential landscape through the niches that are available to different species [9] or by using agent-based simulations of the dynamics of different species in a landscape [67]. These are all promising 
techniques, but some are data intensive and none have been validated for bioenergy cropping. Fortunately, the general principles of what makes a biodiverse agricultural or forest landscape are well understood, and evidence-based strategies for managing landscape change are available [20]. These include maintaining large patches of native/uncropped vegetation with corridors and stepping stones between them, and buffers around them; maintaining appropriate disturbance regimes, maintaining species of particular concern and key species interactions, and controlling aggressive and invasive species [21].

\section{Regional Scale}

One of the concerns about changes to bioenergy policy is the potential to disrupt distant ecosystems by driving production elsewhere at the expense of primary forests and the species within them [45]. Bioenergy cropping is already competing with food production [7], and will in turn influencing global patterns of agriculture and pressures on biodiversity [65]. There may be changes to the intensity of land management. While these may have negative impacts locally on biodiversity at the landscape scale, they may be offset by reducing pressure on further habitat loss [26]; but see [40].

\section{Impacts}

The major potential negative impact of bioenergy policies and large scale programmes is that they will have the effect of increasing pressure on the degradation and loss of more remote habitats and landscapes. Yet this need not happen, especially if they are designed to use land that is no longer biodiverse, but is marginal, recently abandoned or degraded. Indeed, there is the potential for large scale land restoration using bioenergy crops.

The key questions to be asked as part of an assessment are, therefore,

- What is the risk of loss of primary habitat, direct or indirect?

- What is the risk of loss of secondary (non-agricultural) habitat, and potential consequences of that loss?

- Will new habitats be created, and what might be the local and regional benefits to biodiversity?

\section{Methodology}

Analysis at this scale is perhaps most appropriate for the analyses of policy changes. Formal methods involve modelling land use change in response to different economic/policy scenarios, often by allocating pixels of land to different uses.
Such scenarios can have a short-term focus [68] or can be more forward looking and sensitive to higher-order political processes [43, 52]. They are useful for showing broad patterns of potential land use change, rather than for identifying particular threats to particular habitats.

\section{Global Scale}

At the global scale, the major impact of bioenergy programmes is to reduce net greenhouse gas emissions, with consequently better control of global climate change and benefits to biodiversity $[42,61,63]$. Therefore the potential global benefits depend upon a whole life cycle assessment of carbon balance and implications for other greenhouse gases, and how they differ between crop type, production and distribution systems. The key question is, therefore,

- To what extent will the project reduce the net production of greenhouse gases, and what impact will this reduction have on scenarios for future climate change?

Bioenergy projects are being evaluated for their potential to mitigate climate change at a range of scales [2, 24, 32]. It is beyond the scope of this paper to explore the issues involved in estimating the potential impact of new developments on greenhouse gas emissions and hence on climaterelated risks to biodiversity, but it is worth noting the large uncertainties involved, not least in terms of specifying the system to be included. It is also worth noting that the global emissions of greenhouse gases from the loss of natural forests exceeds that of the transport sector, and that curbing deforestation is a "highly cost-effective way to reduce emissions" [61], implying that direct and indirect effects of bioenergy projects on rates of habitat loss need to be taken into account in greenhouse gas budgeting. The potential release of carbon from soils disturbed for the planting of bioenergy crops also needs to be considered.

\section{Towards Good Ecological Practice for Bioenergy Projects}

The ecological implications of any bioenergy development are indeed complex. This is because the impacts vary between scales, in that the conversion of large areas of land to monocultures of bioenergy crops may have locally damaging consequences, but could contribute to the global reduction of greenhouse gas production. The impacts vary among taxa, so, for example, the conversion of grassland to woodland coppice would favour species associated with open woodland habitats at the expense of those that favour more open habitats. There are substantial uncertainties in 
these potential impacts, and strong dependencies on the management of the bioenergy projects across their whole life cycle. And, finally, there are other goals for bioenergy production than the conservation of biodiversity, including energy security and rural development.

A complete assessment therefore involves the balancing of goals across a wide variety of stakeholders, to an even greater extent than has been the case for GM crops. Some of the engagement processes used in the GM crop debate $[33,53]$ offer useful models, but many others are available $[69,72]$. Clearly, complete assessments will prove complex and time consuming. Given that these will be most needed when there are clear conflicts of interest to be resolved, it is better to avoid these conflicts in the first place. This can be done by adopting simple guidelines, drawing upon the existing rich evidence base of interactions between land use and biodiversity. Projects could be favoured that:

- Avoid gene flow to wild relatives in centres of diversity The greatest ecological risk of gene flow from crops to wild relatives is that it may reduce the genetic diversity at centres of origin and diversity [15].

- Do not result in invasion by the crop into other habitats

The risk of invasiveness results from a combination of the characteristics of the plant itself, that can be increased or decreased a result of breeding programmes [50], and of its receiving environment.

- Are biodiversity in their own right

Many biomass cropping programmes can be developed using local varieties of a wide range of species, and so maintaining genetic diversity. It may prove viable to create and manage biodiverse grasslands and woodlands for bioenergy [66].

- Enhance field-scale biodiversity compared with local habitats of equivalent growth forms, taking establishment time into account

It is possible to create habitats and food resources for biodiversity within bioenergy crops. Arable crops can be managed with areas in and around them to provide habitats and food [41, 60, 64], while perennial crops can be managed with varieties, rotations and planting densities that create niches for ground flora and fauna and nesting birds [12, 54, 55].

- Increase landscape diversity

In the majority of agricultural landscapes, increasing the diversity of land cover types and the levels of connecting features increases biodiversity through availability of multiple habitats and the facilitation of dispersion among them [20].

- Do not threaten valued habitats and species within the local landscape

Conservation concerns are often focused on individual species or habitats at the landscape scale. New projects should not replace these habitats, nor threaten them indirectly (e.g. by changing the local hydrology).

- Promote the sustainable management of biodiverse habitats

It may prove possible to manage some habitats for biomass removal, increasing their long term economic value and hence sustainability, or to use bioenergy crops to provide buffers around existing nature reserves.

- Do not increase risk of loss of primary habitats

This risk is most relevant to changes in policies and trading regimes, and includes indirect risks, such as through changes to food markets.

- Result in a proportionately large reduction in greenhouse gas emissions

A whole life cycle approach is needed that takes into account not simply the carbon balance for the crop itself but also potential carbon losses due to land clearance and soil disturbance.

In general, the best way to integrate bioenergy requirements with the conservation of biodiversity is to minimise the conflicts over land use. This will prove easiest for bioenergy projects that take advantage of land that has been used for agriculture, but is currently degraded or recently abandoned. Such land is unlikely to be rich in biodiversity, and its conversion is unlikely to increase pressure for habitat loss elsewhere.

Acknowledgements This research was funded by the BBSRC "Delivering Multifunctional Landscapes" research programme at North Wyke. Many thanks to the referees for their comments.

Open Access This article is distributed under the terms of the Creative Commons Attribution Noncommercial License which permits any noncommercial use, distribution, and reproduction in any medium, provided the original author(s) and source are credited.

\section{References}

1. Adegbidi HG, Volk TA, White EH, Abrahamson LP, Briggs RD, Bickelhaupt DH (2001) Biomass and nutrient removal by willow clones in experimental bioenergy plantations in New York State. Biomass Bioenerg 20:399-411

2. Adler PR, Del Grosso SJ, Parton WJ (2007) Life-cycle assessment of net greenhouse-gas flux for bioenergy cropping systems. Ecol Appl 17:675-691

3. Agriculture and Environment Biotechnology Commission (2001) Crops on trial. Department of Trade and Industry, London

4. Benton TG, Vickery JA, Wilson JD (2003) Farmland biodiversity: is habitat heterogeneity the key? Trends Ecol Evol 18:182-188

5. Brooks DR, Bohan DA, Champion GT, Haughton AJ, Hawes C, Heard MS, Clark SJ, Dewar AM, Firbank LG, Perry JN, Rothery P, Scott RJ, Woiwod IP, Birchall C, Skellern MP, Walker JH, Baker P, Bell D, Browne E, Dewar AJG, Fairfax CM, Garner BH, Haylock LA, Horne SL, Hulmes SE, Mason NS, Norton LR, Nuttall P, Randle Z, Rossall MJ, Sands RJN, Singer EJ, Walker MJ (2003) Responses of invertebrates to contrasting herbicide 
regimes in genetically modified herbicide-tolerant crops. I. Soilsurface-active invertebrates. Philos Trans R Soc B 358:1847-1862

6. Bruinderink GG, Van Der Sluis T, Lammertsma D, Opdam P, Pouwels R (2003) Designing a coherent ecological network for large mammals in northwestern Europe. Conserv Biol 17:549-557

7. Buntrock G (2007) Cheap no more. Economist, 6 December pp 83-85

8. Burel F, Butet A, Delettre YR, Peña NMdl (2004) Differential response of selected taxa to landscape context and agricultural intensification. Landsc Urban Plan 67:195-204

9. Butler SJ, Vickery JA, Norris K (2007) Farmland biodiversity and the footprint of agriculture. Science 315:381-384

10. Decocq G, Aubert M, Dupont F, Alard D, Saguez R, Wattez-Franger A, De Foucault B, Delelis-Dusollier A, Bardat J (2004) Plant diversity in a managed temperate deciduous forest: understorey response to two silvicultural systems. J Appl Ecol 41:1065-1079

11. Dewar AM, May MJ, Woiwod IP, Haylock LA, Champion GT, Garner BH, Sands RJ, Qi A, Pidgeon JD (2003) A novel approach to the use of genetically modified herbicide tolerant crops for environmental benefit. Proc R Soc Lond B Biol Sci 270:335-340

12. Dhondt AA, Wrege PH, Sydenstricker KV, Cerretani J (2004) Clone preference by nesting birds in short-rotation coppice plantations in central and western New York. Biomass Bioenerg 27:429-435

13. Duelli P, Obrist MK (2003) Regional biodiversity in an agricultural landscape: the contribution of seminatural habitat islands. Basic Appl Ecol 4:129-138

14. European Food Standards Agency (2006) Guidance document of the Scientific Panel on Genetically Modified Organisms for the risk assessment of genetically modified plants and derived food and feed. EFSA J 99:1-100

15. Firbank L, Lonsdale M, Poppy G (2005) Reassessing the environmental risks of GM crops. Nat Biotechnol 23:1475-1476

16. Firbank LG, Barr CJ, Bunce RGH, Furse MT, Haines-Young R, Hornung M, Howard DC, Sheail J, Sier A, Smart SM (2003a) Assessing stock and change in land cover and biodiversity: Countryside Survey 2000. J Environ Manage 67:207-218

17. Firbank LG, Heard MS, Rothery P, Scott RJ, Brooks DR, Hawes C, Champion GT, Clark SJ, Dewar AM, Haughton AJ, May MJ, Perry JN, Squire GR (2006) Effects of genetically modified herbicide-tolerant cropping systems on weed seedbanks in following years. Biol Lett 2:140-143

18. Firbank LG, Heard MS, Woiwod IP, Hawes C, Haughton AJ, Champion GT, Scott RJ, Hill MO, Dewar AM, Squire GR, May MJ, Brooks DR, Bohan DA, Daniels RE, Osborne JL, Roy DB, Black HIJ, Rothery P, Perry JN (2003b) An introduction to the farm scale evaluations of genetically modified herbicide-tolerant crops. J Appl Ecol 40:2-16

19. Firbank LG, Petit S, Smart S, Blain A, Fuller RJ (2008) Assessing the impacts of agricultural intensification on biodiversity: a British perspective. Philos Trans Roy Soc B 363:777-787

20. Fischer J, Lindenmayer DB (2007) Landscape modification and habitat fragmentation: a synthesis. Global Ecol Biogeogr 16:265-280

21. Fischer J, Lindenmayer DB, Manning AD (2006) Biodiversity, ecosystem function, and resilience: ten guiding principles for commodity production landscapes. Front Ecol Environ 4:80-86

22. Fuller RJ, Norton LR, Feber RE, Johnson PJ, Chamberlain DE, Joys AC, Mathews F, Stuart RC, Townsend MC, Manley WJ, Wolfe MS, Macdonald DW, Firbank LG (2005) Benefits of organic farming vary among taxa. Biol Lett 1:431-434

23. Gibbons DW, Bohan DA, Rothery P, Stuart RC, Haughton AJ, Scott RJ, Wilson JD, Perry JN, Clark SJ, Dawson RJG, Firbank LG (2006) Weed seed resources for birds in fields with contrasting conventional and genetically modified herbicide-tolerant crops. Proc R Soc Lond B Biol Sci 273:1921-1928

24. Gielen D, Fujino J, Hashimoto S, Moriguchi Y (2003) Modeling of global biomass policies. Biomass Bioenerg 25:177-195
25. Graef F, Zughart W, Hommel B, Heinrich U, Stachow U, Werner A (2005) Methodological scheme for designing the monitoring of genetically modified crops at the regional scale. Environ Monit Assess 111:1-26

26. Green RE, Cornell SJ, Scharlemann JPW, Balmford A (2005) Farming and the fate of wild nature. Science 307:550-555

27. Gustavsson E, Lennartsson T, Emanuelsson M (2007) Land use more than 200 years ago explains current grassland plant diversity in a Swedish agricultural landscape. Biol Conserv 138:47-59

28. Hanski I (1999) Habitat connectivity, habitat continuity, and metapopulations in dynamic landscapes. Oikos 87:209-219

29. Haughton AJ, Champion GT, Hawes C, Heard MS, Brooks DR, Bohan DA, Clark SJ, Dewar AM, Firbank LG, Osborne JL, Perry JN, Rothery P, Roy DB, Scott RJ, Woiwod IP, Birchall C, Skellern MP, Walker JH, Baker P, Browne EL, Dewar AJG, Garner BH, Haylock LA, Horne SL, Mason NS, Sands RJN, Walker MJ (2003) Invertebrate responses to the management of genetically modified herbicide-tolerant and conventional spring crops. II. Within-field epigeal and aerial arthropods. Philos Trans R Soc B 358:1863-1877

30. Heard MS, Clark SJ, Rothery P, Perry JN, Bohan DA, Brooks DR, Champion GT, Dewar AM, Hawes C, Haughton AJ, May MJ, Scott RJ, Stuart RS, Squire GR, Firbank LG (2006) Effects of successive seasons of genetically modified herbicide-tolerant maize cropping on weeds and invertebrates. Ann Appl Biol 149:249-254

31. Heard MS, Hawes C, Champion GT, Clark SJ, Firbank LG, Haughton AJ, Parish A, Perry JN, Rothery P, Scott RJ, Skellern M, Squire GR, Hill MO (2003) Weeds in fields with contrasting conventional and genetically modified herbicide-tolerant crops. 1 . Effects on abundance and diversity. Philos Trans R Soc B 358:1819-1832

32. Heller MC, Keoleian GA, Volk TA (2003) Life cycle assessment of a willow bioenergy cropping system. Biomass Bioenerg 25:147-165

33. Heller R (2003) GM nation? The findings of the public debate. Department of Trade and Industry, London

34. Hendrickx F, Maelfait JP, Van Wingerden W, Schweiger O, Speelmans M, Aviron S, Augenstein I, Billeter R, Bailey D, Bukacek R, Burel F, Diekotter T, Dirksen J, Herzog F, Liira J, Roubalova M, Vandomme V, Bugter R (2007) How landscape structure, land-use intensity and habitat diversity affect components of total arthropod diversity in agricultural landscapes. J Appl Ecol 44:340-351

35. Hermy M, Verheyen K (2007) Legacies of the past in the presentday forest biodiversity: a review of past land-use effects on forest plant species composition and diversity. Ecol Res 22:361-371

36. Heywood VH, Watson C (1995) Global biodiversity assessment. United Nations Environment Program. Cambridge University Press, Cambridge

37. Hoenicka H, Fladung M (2006) Biosafety in Populus spp. and other forest trees: from non-native species to taxa derived from traditional breeding and genetic engineering. Trees 20:131-144

38. Jordan N, Boody G, Broussard W, Glover JD, Keeney D, McCown BH, McIsaac G, Muller M, Murray H, Neal J, Pansing C, Turner RE, Warner K, Wyse D (2007) Environment - sustainable development of the agricultural bio-economy. Science 316:1570-1571

39. Krebs JR, Wilson JD, Bradbury RB, Siriwardena GM (1999) The second silent spring? Nature 400:611-612

40. Matson PA, Vitousek PM (2006) Agricultural intensification: will land spared from farming be land spared for nature? Conserv Biol 20:709-710

41. May MJ, Champion GT, Dewar AM, Qi AM, Pidgeon JD (2005) Management of genetically modified herbicide-tolerant sugar beet for spring and autumn environmental benefit. P Roy Soc Lond B Bio 272:111-119 
42. Metz B, Davidson OR, Bosch PR, Dave R, Meyer LA (2007) Climate Change 2007: mitigation. Contribution of Working Group III to the Fourth Assessment Report of the Intergovernmental Panel on Climate Change. Cambridge University Press, Cambridge

43. Millennium Ecosystem Assessment (2005) Synthesis report. Island, Washington, DC

44. OECD (1993) OECD Core set of indicators for environmental performance reviews. OECD, Paris

45. Palmer MW (2007) Biofuels and the environment. Science 317:897

46. Perry JN, Rothery P, Clark SJ, Heard MS, Hawes C (2003) Design, analysis and statistical power of the Farm Scale Evaluations of genetically modified herbicide-tolerant crops. J Appl Ecol 40:17-31

47. Petit S, Burel F (1998) Effets of landscape dynamics on the metapopulation of a ground beetle (Coleoptera, Carabidae) in a hedgerow network. Agric Ecosyst Environ 69:243-252

48. Petit S, Chamberlain D, Haysom K, Pywell R, Vickery J, Warman L, Allen D, Firbank L (2003) Knowledge-based models for predicting species occurrence in arable conditions. Ecography 26:626-640

49. Poppy GM, Wilkinson MJ (2005) Gene flow from GM plants. Blackwell, Oxford

50. Raghu S, Anderson RC, Daehler CC, Davis AS, Wiedenmann RN, Simberloff D, Mack RN (2006) Adding biofuels to the invasive species fire? Science 313:1742

51. Reyers B, Rouget M, Jonas Z, Cowling RM, Driver A, Maze K, Desmet $P$ (2007) Developing products for conservation decisionmaking: lessons from a spatial biodiversity assessment for South Africa. Divers Distrib 13:608-619

52. Rounsevell MDA, Reginster I, Araujo MB, Carter TR, Dendoncker N, Ewert F, House JI, Kankaanpaa S, Leemans R, Metzger MJ, Schmit C, Smith P, Tuck G (2006) A coherent set of future land use change scenarios for Europe. Agric Ecosyst Environ 114:57-68

53. Royal Commission on Genetic Modification (2002) Report of the Royal Commission on genetic modification. New Zealand Ministry for the Environment, Wellington

54. Sage R, Cunningham M, Boatman N (2006) Birds in willow short-rotation coppice compared to other arable crops in central England and a review of bird census data from energy crops in the UK. Ibis 148:184-197

55. Sage RB, Robertson PA (1996) Factors affecting songbird communities using new short rotation coppice habitats in spring. Bird Study 43:201-213

56. Sears MK, Hellmich RL, Stanley-Horn DE, Oberhauser KS, Pleasants JM, Mattila HR, Siegfried BD, Dively GP (2001) Impact of Bt corn pollen on monarch butterfly populations: a risk assessment. Proc Natl Acad Sci USA 98:11937-11942

57. Sims REH, Hastings A, Schlamadinger B, Taylor G, Smith P (2006) Energy crops: current status and future prospects. Glob Change Biol 12:2054-2076
58. Smart SM (2000) Ecological assessment of vegetation from a nature reserve using regional reference data and indicator scores. Biodivers Conserv 9:811-832

59. Smart SM, Bunce RGH, Firbank LG, Coward P (2002) Do field boundaries act as refugia for grassland plant species diversity in intensively managed agricultural landscapes in Britain? Agric Ecosyst Environ 91:73-87

60. Sotherton NW (1991) Conservation headlands: a practical combination of intensive cereal farming and conservation. In: Firbank LG, Carter N, Darbyshire JF, Potts GR (eds) The ecology of temperate cereal fields. Blackwell, Oxford, pp 373-397

61. Stern N (2007) The economics of climate change; the Stern review. Cambridge University Press, Cambridge

62. Termorshuizen JW, Opdam P, van den Brink A (2007) Incorporating ecological sustainability into landscape planning. Landsc Urban Plan 79:374-384

63. Thomas CD, Cameron A, Green RE, Bakkenes M, Beaumont LJ, Collingham YC, Erasmus BFN, Siqueira MFd, Grainger A, Hannah L, Hughes L, Huntley B, Jaarsveld ASv, Midgley GF, Miles L, Ortega-Huerta MA, Peterson AT, Phillips OL, Williams SE (2004) Extinction risk from climate change. Nature 427:145-148

64. Thomas SR, Noordhuis R, Holland JM, Goulson D (2002) Botanical diversity of beetle banks effects of age and comparison with conventional arable field margins in southern UK. Agric Ecosyst Environ 93:403-412

65. Tilman D, Fargione J, Wolff B, D'Antionio C, Dobson A, Howarth R, Schindler D, Schlesinger WH, Simberloff D, Swackhamer D (2001) Forecasting agriculturally driven global environmental change. Science 292:281-284

66. Tilman D, Hill J, Lehman C (2006) Carbon-negative biofuels from low-input high-diversity grassland biomass. Science 314:1598-1600

67. Topping CJ, Hansen TS, Jensem TS, Jepsen JU, Nikolajsen F, Odderskaer P (2003) ALMaSS, an agent-based model for animals in temperate European landscapes. Ecol Model 167:65-82

68. Verburg PH, Soepboer W, Veldkamp A, Limpiada R, Espaldon V, Mastura SSA (2002) Modeling the spatial dynamics of regional land use: The CLUE-S model. Environ Manage 30:391-405

69. Vogel C, Moser SC, Kasperson RE, Dabelko GD (2007) Linking vulnerability, adaptation, and resilience science to practice: Pathways, players, and partnerships. Global Environ Chang 17:349-364

70. Weibull AC, Ostman O, Granqvist A (2003) Species richness in agro-ecosystems: the effects of landscape, habitat and farm management. Biodivers Conserv 12:1334-1355

71. Wilkinson MJ, Davenport IJ, Charters YM, Jones AE, Allainguillaume J, Butler HT, Mason DC, Raybould AF (2000) A direct regional scale estimate of transgene movement from genetically modified oilseed rape to its wild progenitors. Mol Ecol 9:983-991

72. Wittmer H, Rauschmayer F, Klauer B (2006) How to select instruments for the resolution of environmental conflicts? Land Use Policy 23:1-9 